\title{
EFFECT OF PROBIOTIC AND PRILLED FAT ON LACTATION PERFORMANCE OF CROSS BRED COW DURING TRANSITION PERIOD
}

\author{
Meeti Punetha ${ }^{1}$, AK Roy ${ }^{1}$, Irshad Ahmed Para ${ }^{1}$, Deepanshu Gupta ${ }^{1}$, Nitika Singh Jalmeria ${ }^{1}$, \\ Yogesh Pandey ${ }^{2}$, Mahendra Singh ${ }^{1 *}$
}

\footnotetext{
${ }^{1}$ Division of Animal Physiology, ICAR- National Dairy Research Institute, Karnal-132001 (Haryana)

${ }^{2}$ Physiology and Climatology Division, ICAR-Indian Veterinary Research Institute (Izatnagar)
}

Received - January 12, 2018; Revision - July 05, 2018; Accepted - July 09, 2018

Available Online - August 10, 2018

DOI: http://dx.doi.org/10.18006/2018.6(4).746.750

\author{
KEYWORDS \\ Saccharomyces cerevisiae \\ Prilled fat \\ Milk yield \\ Profit/cow/day \\ Fat
}

* Corresponding author

E-mail: chhokar.ms@gmail.com (Mahendra Singh)

Peer review under responsibility of Journal of Experimental Biology and Agricultural Sciences.

Production and Hosting by Horizon Publisher India [HPI] (http://www.horizonpublisherindia.in/).

All rights reserved.

\begin{abstract}
In present study, combined effects of prilled fat and yeast culture (YC) mixture supplemented diet on 12 early lactating crossbred cows were evaluated. Cows were divided into two groups as control group (CON group) and supplemented group (SG). Animal of CON group were fed on wheat straw, maize fodder and concentrate mixture, while animal of supplemented group were additionally supplemented with $100 \mathrm{~g} / \mathrm{d}$ prilled fat, $25 \mathrm{~g} / \mathrm{d}$ Saccharomyces cerevisiae (SC)/day and sweetener $1 \mathrm{~g} / \mathrm{d}$ from 30 day prepartum to 30 days postpartum. The effect of feeding on milk production was monitored up to 60 day of lactation. Result of study revealed that milk yield was increased ( $p<0.01)$ by $9.76 \%$ in SG than the control group $(14.77 \pm 0.34 \mathrm{~kg} / \mathrm{d}$ vs $13.44 \mathrm{~kg} / \mathrm{d} \pm 0.44)$. Further, Milk fat yield was also increased $(\mathrm{p}<0.01)$ by $5.91 \%$ in SG than the CON. The overall net average profit was Rs $77.77 /$ cow/day assuming selling price of milk@ Rs 50/kg milk at 3.5\% FCM. The overall net daily gain of milk kg/day/cow due to supplementation mixture was $1.76 \mathrm{~kg}$.
\end{abstract}

All the article published by Journal of Experimental Biology and Agricultural Sciences is licensed under a Creative Commons Attribution-NonCommercial 4.0 International License Based on a work at www.jebas.org.

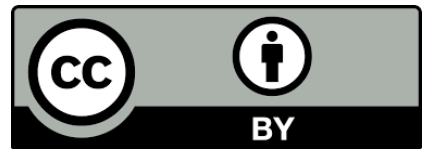




\section{Introduction}

In developing countries like India most of the animals are fed agriculture by-products and low quality crop residues which have low nutritive value and digestibility. Increased nutrient demand and limited feed intake during early lactation affects production potential and cause an increase in energy demand (Sirohi et al., 2010). Due to this reason animals mobilizes its body reserves to satisfy energy requirements (negative energy balance) leading to substantial loss in body weight and lower milk yield (Kim et al., 2003). Supplementation of bypass fat increases energy intake shows more economic returns to dairy farmers (Parnerkar et al., 2010). The previous results on effect of prilled fat containing vegetable palm oil have shows significant impact on milk yield and fat percentage in cows and buffaloes (Rajesh, 2013; Yadav et al., 2015; Singh et al., 2015; Sharma et al., 2016). Similar to prilled fat, the yeast supplementation in the diet of animals can modify microbial fermentation and digestion in the rumen. Studies have shown the positive effects of yeast culture on rumen environment and its microbial activities (Chevaux \& Fabre, 2007).Yeast culture used as a dietary supplement for dairy cattle improve rumen function, which in turn improve milk production and feeding efficiency, by stimulating selective growth of rumen bacteria species (Harrison et al., 1995). Yeast stimulates cellulolytic bacteria in the rumen, increase fiber digestion and flow of microbial protein from the rumen (Newbold et al., 1996; Jouany \& Morgavi, 2007). The effect of prilled fat and $S$. cerevisiae feeding on milk production has been reported but the combined effect of supplementation on the economics has not been studied. Therefore, present study was conducted to investigate the effect of $S$. cerevisiae and prilled fat feeding concurrently on economics of feeding in crossbred cows.

\section{Materials and Methods}

\subsection{Experimental site and animals}

National Dairy Research Institute, Karnal is situated at an altitude of 250 meter above mean sea level, latitude and longitude position being $29^{\circ} 42^{\prime \prime} \mathrm{N}$ and $79^{\circ} 54^{\prime \prime} \mathrm{E}$, respectively. The maximum ambient temperature in summer goes up to $45^{\circ} \mathrm{C}$ and minimum temperature in winter comes down to $<1{ }^{\circ} \mathrm{C}$ with a diurnal variation in the order of $15-20^{\circ} \mathrm{C}$. The average annual rainfall is $700 \mathrm{~mm}$, most of which is received from early July to mid September. For the present study, 12 Karan Fries (KF) cows at 45 days pre-partum were selected from the herd of National Dairy Research Institute (NDRI) Karnal.

\subsection{Experimental Design}

The experimental crossbred cows (Holstein Friesian $\mathrm{x}$ Thaparkar) were divided into two groups of six animals each on the basis of
MPPA. Six cows were kept as control and fed as per the standard feeding practices followed at NDRI farm. While the rest six experimental cows were supplemented daily with prilled fat @100g/cow, S. cerevisiae@ 25g/cow and sweetener@1g/cow in addition to the standard feeding practices from -30 days of prepartum until 30 days of lactation. Milk yields of the cows were recorded daily up to 30 days of lactation. Milk samples were collected on 7, 14, 21 and 30 days from both the groups of cows and analyzed for fat, protein, lactose, and SNF by milk analyzer.

\section{Result}

The average milk production was lower in control $(13.44 \mathrm{~kg} / \mathrm{d})$ than the supplemented group $(14.77 \mathrm{~kg} / \mathrm{d})$. The milk yield was $9.76 \%$ higher in SG than that of control group cows (Figure 1). The milk fat and protein increased by $5.91 \%$ and $6.47 \%$ respectively in the supplemented as compared to control group cows (Figure 2, 3). Feeding of prilled fat @100g/day/cow, S. cerevisiae@25g/day and sweetener@1g/day during prepartum and postpartum was found to be economical and beneficial. Supplementation of prilled fat along with $S$. cerevisiae and sweetener costs Rs.13.4; in which cost of prilled fat is Rs $80 / \mathrm{kg}$, S. cerevisiae cost Rs. $210 / \mathrm{Kg}$ and sweetener Rs150/kg. On supplementation of prilled fat, milk yield was significantly $(\mathrm{P}<0.01)$ increased and fat percentage was also significantly $(\mathrm{P}<0.01)$ higher. The milk yield at $3.5 \% \mathrm{FCM}$ at different weekly interval was calculated. The overall net average profit was Rs 77.77/cow/day assuming selling price of milk @ Rs 50/kg milk at $3.5 \%$ FCM. The overall net daily gain of milk $\mathrm{kg} / \mathrm{day} / \mathrm{cow}$ due to supplementation mixture was $1.76 \mathrm{~kg}$ (Table 1)

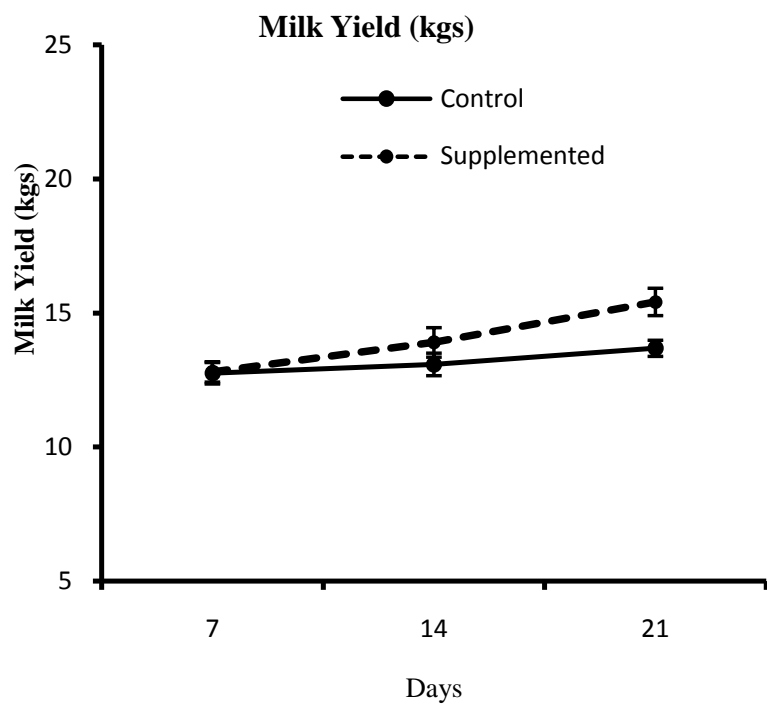

Figure 1 Effect of supplemented diet on milk yield 


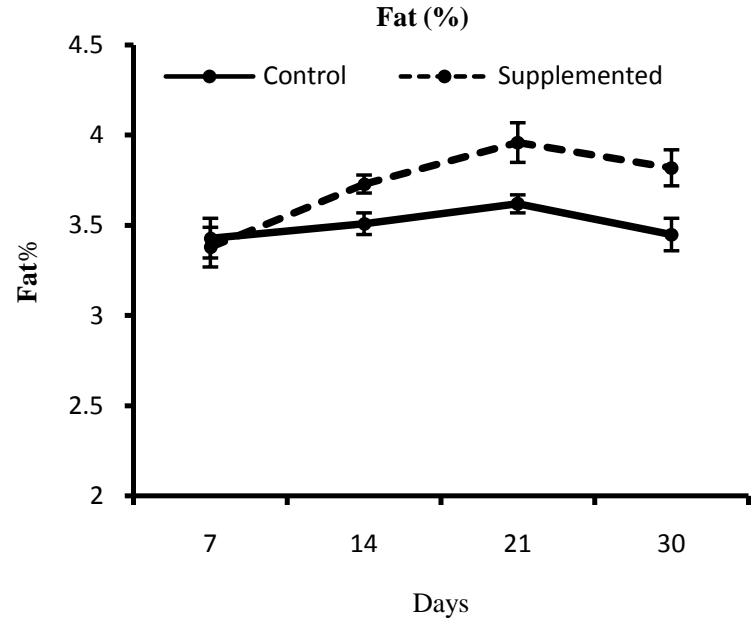

Figure 2 Effect of supplemented diet on milk fat percentage

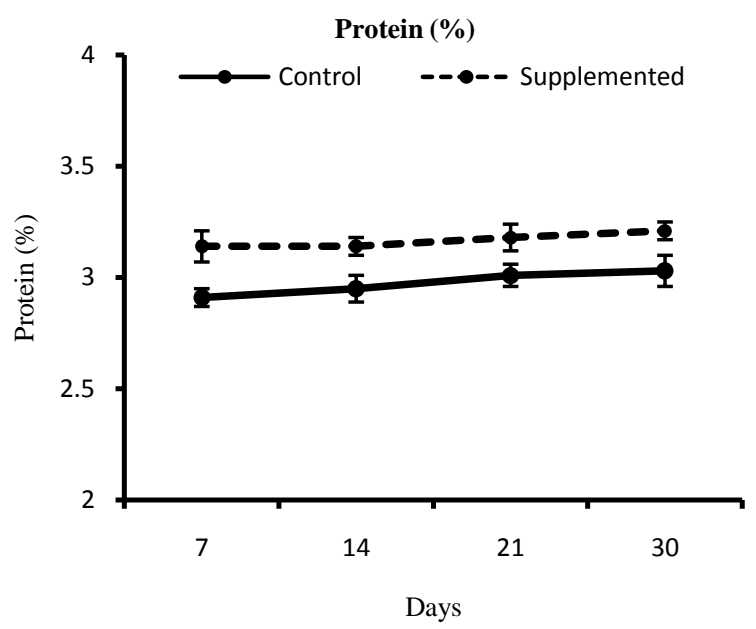

Figure 3 Effect of supplemented diet on milk proetin percentage

Table 1 Cost benefit Ratio

\begin{tabular}{|c|c|c|}
\hline \multicolumn{3}{|c|}{ Cost-benefit ratio } \\
\hline Input cost & C group & S group \\
\hline \multirow[t]{2}{*}{ cost of green fodder(@Rs 3/kg) taken by 12 cows @ $30 \mathrm{Kg} /$ day } & $30 * 6 * 3$ & $32 * 6 * 3$ \\
\hline & Rs 540 & Rs 576 \\
\hline \multirow[t]{2}{*}{ cost of dry fodder(@Rs 5/kg) taken by 12 cows @ $5 \mathrm{Kg} /$ day } & $5 * 6 * 8.5$ & $5 * 6 * 8.9$ \\
\hline & Rs 255 & Rs 267 \\
\hline cost of concentrate(@Rs 22/kg) taken by 12 cows @3/Kg day & $3 * 6 * 22=\operatorname{Rs} 396$ & $3 * 6 * 22=\operatorname{Rs} 396$ \\
\hline \multicolumn{2}{|c|}{ cost of FYC (@Rs 350/kg) prilled fat plus S.C and sweetener taken by cows per day } & $8+5.25+0.15=13.4$ \\
\hline Total input cost & Rs 1191 & Rs 1252.4 \\
\hline Output cost & C group & S group \\
\hline FCM $(3.5 \%)$ yield of 12 cows per day & 13.43 & 15.19 \\
\hline cost of milk(@ $@ 50 / \mathrm{kg}$ ) produced from one animal per day & $13.43 * 50=\operatorname{Rs} 671.5$ & $15.19 * 50=\operatorname{Rs} 759.5$ \\
\hline Increased yield /day/cow & $15.19-13.43$ & $1.76 \mathrm{~kg}$ \\
\hline Increased profit /day/cow & $1.76 * 50$ & Rs 88 \\
\hline actual profit/cow/day, -cost of FYC & $88-10.23=$ & Rs 77.77 \\
\hline Cost: benefit ratio & $10.23 / 77.77$ & $1: 7$ \\
\hline
\end{tabular}

Journal of Experimental Biology and Agricultural Sciences http://www.jebas.org 


\section{Discussion}

The increases in milk production in supplemented group of crossbred cows suggest that the mixture of prilled fat and $S$. cerevisiae is galactopoitic and sustained the milk production during the experiment. However, the inclusion of sweetener was supposed to enhance the palatability of feed. Sharma et al. (2016) observed that milk yield increased significantly at $2 \mathrm{~kg} /$ day during different weeks of the experiment in SG in comparison to CG. The greater response in milk yield and fat content in crossbred cows indicated that energy was limiting the milk production. Similar results on milk yield have been reported earlier in midlactating cows fed with prilled fat $75 \mathrm{~g} / \mathrm{d}$ (Singh et al., 2014) and in buffaloes maintained in organized farm of the institute (Singh et al., 2015). Ranjan et al. (2012) concluded that bypass fat supplementation with $1.4 \%$ of dry matter intake (200g/day) increased the milk production and feed efficiency in lactating Murrah buffaloes. Rajesh (2013) reported an improvement of $6.02 \%$ in milk yield of early lactating crossbred cows fed $75 \mathrm{~g} / \mathrm{d} / \mathrm{animal}$ prilled fat. The significant increase in milk production associated with yeast supplementation have previously been reported in dairy cows (Bruno et al., 2009). Yeast supplemented @ 15g/day, showed a significant $(\mathrm{P}<0.05)$ improvement in milk yield $(8.8 \%)$, protein content $(\mathrm{P}<0.05)$ and SNF in cross bred cows (Hossain et al., 2012). Formigoni et al. (2005) reported that Yea-Sacc $® 1026$ improved significantly the DMI and milk yield of dairy cows, on the overall period, but also, during heat stress period. Yea-Sacc $® 1026$ improved significantly the composition of cows milk, including fat $(\mathrm{P}<0.01)$ and protein $(\mathrm{P}<0.05)$ content. An increase in milk yield due to yeast culture feeding usually ranged between 1 and $2 \mathrm{~kg}$ /day (Robinson \& Garrett, 1999). A positive effect of yeasts on the performance of dairy cows resulted in increased daily feed intake and improved digestibility of nutrients or change in rumen parameters. Ayad et al., (2013) observed that when $S$. cerevisiae was given 20 g/day the average milk production per cow was reported between the all experiment groups (by about $+25 \%$, i.e. $4.81 /$ day/cow), with a positive effect in milk fat content. The significant increase in milk protein in SG is due to increase in VFA production by yeast culture (S. cerevisiae) which in turn increases milk proteins (Oetzel et al., 2007).

\section{Conclusion}

Supplementation of a mixture of prilled fat along and S. cerevisiae with sweetener significantly improves milk yield and fat percent. Further being cost effective it could be used successfully to augment the productive performance of cows. The increase in milk yield, milk fat, milk protein and more profitability by INR 77/day/animal indicate its important role in sustaining the rural livelihood in the near future.

\section{Ethical Procedure}

The experimental protocol was duly cleared by the Institute Animal Ethics Committee.

\section{Acknowledgements}

The authors thank Director, ICAR-National Dairy Research Institute Karnal for providing necessary facilities for the above research work. The grant used under BRNS project no. 2013/35/48-RTAC, Mumbai is thankfully acknowledged.

\section{Competing Interests}

The authors declare that they have no competing interests.

\section{Reference}

Ayad MA, Benallou B, Saim MS, Smadi MA, Meziane T (2013) Impact of Feeding Yeast Culture on Milk Yield, Milk Components, and Blood Components in Algerian Dairy Herds. Journal of Veterinary Science Technology 4: 135.

Bruno RG, Rutigliano HM, Cerri RL, Robinson PH, Santos JE (2009) Effect of feeding Saccharomyces cerevisiae on performance of dairy cows during summer heat stress. Animal Feed Science and Technology 150: 175-186.

Chevaux E, Fabre MM (2007) Probiotic yeast in small ruminants. Feed Mixture 15: 28- 29.

Formigoni A, Pezzi P, Tassinari M, Bertin G, Andrieu S (2005) Effect of yeast culture (Yea-Sacc®1026) supplementation on Italian dairy cow performance. Proceedings of the 21st Annual Symposium Nutritional Biotechnology in the Feed and Food Industries, (Suppl. 1), Lexington, KY, USA (May 23-25) Pp. 125.

Harrison JH, Kincaid RL, McNamara JP, Waltner S, Loney KA, Riley RE (1995) Effect of whole cotton seeds and calcium salts of long-chain fatty acids on performance of lactating dairy cows. Journal of Dairy Science 78:181-193.

Hossain S, Parnerkar N, Haque R, Gupta D, Kumarand A, Tyagi $\mathrm{K}$ (2012) Influence of dietary supplementation of live yeast (Saccharomyces cerevisiae) on nutrient utilization, ruminal and biochemical profiles of Kankrej calves. International Journal of Applied Animal Sciences $1: 30-38$.

Jouany JP, Morgavi DP (2007) Use of 'natural' products as alternatives to antibiotic feed additives in ruminant production. Animal 1: 1443-1466. 
Kim MS, Yoon CY, Park KH, Shin CS, Park KS, Kim SY, Cho BY, Lee HK (2003) Changes in ghrelin and ghrelin receptor expression according to feeding status. Neuroreport 14:1317-1320.

Newbold CJ, Wallace RJ, Mcintosh FM (1996) Mode of action of the yeast Saccharomyces cerevisiae as a feed additive for ruminants. British Journal of Nutrition 76: 249- 261.

Oetzel GR, Emery KM, Kautz WP, Nocek JE (2007) Direct-Fed Microbial Supplementation on Health and Performance of Preand Postpartum Dairy Cattle: A Field Trial. Journal of Dairy Science 90: 2058-2068.

Parnerkar S, Kumar D, Shankhpal SS, Thube H (2010) Effect of feeding bypass fat to lactating buffaloes during early lactation. In Proc. of 7th Biennial Animal Nutrition Association Conference, Orissa University of Agriculture and Technology, Bhubaneswar, India, Pp. 126-131.

Rajesh G (2013) Studies on Postpartum physiological adaptation in hormones, metabolites and milk production in crossbred cows fed with prilled fat. MVSc thesis submitted to NDRI, Karnal, Haryana, India.

Ranjan A, Sahoo B, Singh VK, Srivastava S, Singh SP, Pattanaik AK (2012) Effect of bypass fat supplementation on productive performance and blood biochemical profile in lactating Murrah
(Bubalus bubalis) buffaloes. Tropical Animal Health Production 44: 1615-1621.

Robinson PH, Garrett JE (1999) Effect of yeast culture (Saccharomyces cerevisiae) on adaptation of cows to postpartum diets and on lactational performance. Journal of Animal Science 77: 988-999.

Sharma S, Singh M, Roy AK, Thakur S (2016) Effect of pre-partum prilled fat supplementation on feed intake, energy balance and milk production in Murrah buffaloes. Veterinary World 9 : 256-259.

Singh M, Roy AK, Sharma S (2015) Augmentation of milk production by supplementing bypass fat in dairy animals. Asian Journal Animal of Veterinary Advances 10: 476-488.

Singh M, Sehgal JP, Roy AK, Pandita S, Rajesh G (2014) Effect of prilled fat supplementation on hormones, milk production and energy metabolites during mid-lactation in crossbred cows. Veterinary World 7: 384-388.

Sirohi SK, Walli TK, Mohanta RK (2010) Supplementation effect of bypass fat on production performance of lactating crossbred cows. Indian Journal of Animal Sciences 80: 733.

Yadav G, Roy A K, Singh M (2015) Effect of prilled fat supplementation on milk production performance of crossbred cows. Indian Journal of Animal Nutrition 32: 133-138. 